\title{
J. D. Hamilton Dickson, M.A.
}

By the death of Mr J. D. Hamilton Dickson, Cambridge has lost a man whose mental alertness and youthfulness at an advanced age was a source of envy to many of his physically younger acquaintances.

The son of a Glasgow physician, he was born there on 1st May 1849, and received his education at Glasgow University, where he distinguished himself especially on the mathematical and physical side. Working in the laboratory, as was the practice then of only a few of the Natural Philosophy students, he had the privilege of helping the late Lord Kelvin in his determination of the relation between the electromagnetic and electrostatic units of electricity, and in some of his work connected with deep-sea cables.

In 1870 he proceeded to Cambridge, forming a connection with that University that was to last over sixty years, and it is not to be wondered at that he chose to follow Kelvin's footsteps and enter his name as an undergraduate of Peterhouse, which at that time had the double reputation of being both very mathematical and Scottish in bias, a tradition which he himself helped to keep up by becoming Fifth Wrangler in 1874. In 1877 he was appointed Tutor of the College, a post he held for twenty years, and when Lord Kelvin died in 1907 became Senior Fellow. The present writer first met him when he entered Peterhouse, and was immediately struck by the great pains that Dickson took to make all arrangements clear and impossible to be misunderstood by the raw undergraduate. This carefulness was chaŗacteristic of all his work. He had very considerable teaching abilities, too, for while almost any man of average ability can instruct clever pupils, he did the more difficult thing and laid himself out to teach the less clever, in which effort he did very useful work. While very successful as a tutor, he was not so successful as his merits deserved, perhaps owing to this very capacity for detail, dislike of loose ends, and love of order: things too often unappreciated by the ordinary undergraduate, recently released from the bonds of school and feeling his freedom. His mathematical mind may have been too much inclined to arrange every detail of the puzzle, and to be too much upset when every last little piece did not fit in quietly and exactly into its place. But he was much liked, and the College owed a great deal to his firm and energetic supervision. This supervision was not confined to mere discipline, for 
among the other interests of a versatile man, he took a keen interest in music and was a shining light of the Peterhouse Musical Society.

When the War broke out both his patriotism and his energy were shown by his taking up mathematical work on the depleted staffs of Fettes and the Edinburgh Academy, where his physical activity occasioned remark even at that time of resuscitation of "dugouts." A rumour that he had been rebuked by those in authority for being caught sliding down a banister was probably untrue, but gave a truer picture of his vitality than the plain truth would have done. Even quite near his end he was taking a keen interest in the approaching Centenary of Clerk Maxwell, who had been a Peterhouse man before he migrated to Trinity.

While most of his life was spent in Cambridge, he had an Edinburgh connection, for in addition to his election to this Society in 1876 he, like his brother Lord Scott Dickson, and his brother-in-law, Sir James Dewar, married an Edinburgh lady, one of the three Misses Banks, by whom he is survived. He died on 6th February 1931 at the age of 81.

M. M'C. F. 